\title{
What Is There in Common between Arab Revolutions and the Coase Theorem?
}

\author{
Gennady Bilych \\ Dept. of Management, UPEC Corporation, Belgorod \\ 20 Popova str., 308000, Belgorod, Russia
}

Tel: 7-472-220-2033Ｅ-mail: genatdht@yandex.ru

Received: January 22, 2013 Accepted: February 5, 2013

doi:10.5296/ber.v3i1.3094ＵRL: http://dx.doi.org/10.5296/ber.v3i1.3094

\begin{abstract}
Great achievements are rarely accompanied by quick success. This is because revolutionary ideas normally involve a wider range of problems than at first thought. After a period of fair and unfair criticism there follows a period of sober and fruitful discussion. Only after this comes the time of practical application and final development of the new idea. The Coase Theorem is now at its final stage of development. This is confirmed by the recent emergence of studies that I believe to be very promising involving qualitative measurements of transaction costs of exchange and the history of their changes over the centuries. In some of the studies, the view is expressed that the form of ownership of production facilities depends on the amount of transaction costs. With that said we are only one step away from the important conclusion that with a sufficiently high level of transaction costs and a low level of labor productivity, private ownership is not possible and a firm must be very large and may occupy the entire area of a state. This may be the reason why there were powerful centralized economies run by a czar, a king, a feudal lord or a pharaoh. The complex irrigation systems of the Nile required constant joint efforts of tens and hundreds of thousands of people under the central leadership and control of a supreme ruler. This was the only way to achieve a maximum level of production and an acceptable standard of living and have protection from foreign enemies in those times. This and other conclusions, which I hope deserve a certain amount of attention, form the basis of this essay.
\end{abstract}

Keywords: Coase Theorem, Transaction Costs, Private Ownership, Economic Growth 


\section{Introduction}

The significant contribution made by Coase to the development of economic science is clear and is not disputed by anybody today. Just one question remains: how great is this contribution? At present there is no consensus regarding this issue. There are still criticisms of his views and there are doubts on his conclusions, we will never be able to reach a consensus in assessing the legacy of Coase. There are three main claims to the Coase Theorem. The first claim is that Coase supposedly ignored the important role of economic and political institutes in society and their influence on overall welfare (North, 2005; Johnson, 2000). The second problem is linked to the uncertain role of the government in the event of "market failure" (for example: Bowles, 2004). Under what circumstances should the government interfere with the functioning of the market and when should it not? Nowadays, the level of government intervention in the economy depends, to a considerable extent, on the political views of decision-makers. But this is not how it should be. Despite the fact that Coase spoke quite clearly about this matter, there are still claims against him. This is understandable because the value of any theory, in the opinion of the majority of people, depends on its practical application and on how much the theory will help to improve life and raise the standard of welfare. At present there is a widespread view that virtually all market imperfections require government intervention. Of course, after government intervention there is no possibility of assessing the effectiveness of the market solution to the problem. For this reason, many specialists and the general public believe that the result obtained is the best possible result. This means that nobody is at all interested in measuring and comparing market transaction costs and government centralised expenses for resolving a certain issue. As a result of this, nobody is able to say anything specific about the effectiveness of the current economic policy. Of course this claim to the Coase Theorem should be regarded as somewhat farfetched because Coase only outlined the main route to solving the problem and further steps had to be made by numerous followers. Coase in fact did a great deal in this respect, but these efforts were not fully appreciated because the discussion of his work was mainly focused on the appealing, alluring and fantastical world of zero transaction costs. The third claim was linked with the inability to adequately formulate the so-called Coase Theorem. It was described as deep, revolutionary, erroneous (De Mesa, 1987), tautological and false (Cooter, 1987). According to Stigler (1966), Coase simply "told us what we should already have known". Of course Coase never attempted to formulate a theorem. However, it is now extremely desirable to finally shed light on this matter because a formula of the theorem that is acceptable to all or to the majority will help to avoid any unnecessary disputes and channel the efforts of many researchers in a more creative way. Let us now take a more detailed look at these three issues and try to discuss possible ways of resolving them.

\subsection{Institutes}

As North (1990) rightly noted, political and economic institutes set the rules of play and organisations and individuals play the game. Institutes are important and nobody has disputed this statement for a long time. Coase did not dispute the defining value of institutes either. He merely warned that laws and the activity of the government might not only lower the costs of market interaction, but also raise them. He rightly criticized the opinion of Pigou (1920), which 
stated that the government interfered excessively in cases of market externalities. Coase proved that very often the market itself is able solve problems that occur and no further intervention is needed. The institutes themselves can generate transaction costs of exchange. Taxes are a clear example of this. It is clear that many acts of market exchange are blocked due to taxes. If the benefits from a certain transaction are less than the amount of tax to be paid if the deal is implemented then the transaction will not be performed. Coase was right when he stated that the size of firms increases along with their tax rates. Firms are obliged to carry out certain operations themselves rather than using the services of third parties because external transactions will generate additional taxes. Perhaps this is one of the reasons for the increase in relative and absolute sizes of organisations in the first half of the $20^{\text {th }}$ century. Institutes change during the evolution of human society. They cannot be planned. The overall scheme of institutes does not develop in a person's mind (Schneider, 1963). People create them by method of trial and error (Romer, 2003). Political groups and particular individuals also play an important role in this process (Banerjee, Gertler and Ghatak, 2002). The result depends on the political power of the different groups, the powers of persuasion of leaders and the level of education of the remaining members of society. Institutes depend on the benefits that particular individuals and various groups of the population receive thanks to their actions. The quality of institutes most certainly depends on the previous history of the development of the country or region (Djankov and LaPorta, 2003; Gleaser and Shleifer, 2002). Laws and forms of government may bear the familiar traits of their predecessors for a long time. This is why there are institutes that are successful, unsuccessful and overtly poor. The successful institutes that were created through the efforts of Genoese merchants predetermined their victory in the Mediterranean trade war with the Maghreb merchants (Greif, 1994). The successful evolution of political and economic laws enabled the West to occupy leading positions throughout the world during the $10^{\text {th }}$ to the $18^{\text {th }}$ centuries (Greif, 2006). What are people guided by when they try to create certain institutions? What goals do they intend to achieve? There is no consensus among economists in regard to this issue and there is still no absolute clarity. Of course, every individual pursues his or her personal self-interests because, it would seem, there is no common vector of development or changes in laws. But there should be; vectors cannot go in opposite directions because this would create insurmountable obstacles for the development of society and would not enable institutes to be improved. Bridgeman (1955) argues that in order to understand people's behaviour one has to study carefully and closely examine the function of human mind. Jenkins (1980) believes that the main objectives and the main aims of human institutes, including the law, come from human nature itself and he thinks that we have to continue to actively study the particular characteristics of human behaviour. According to Williamson (1985), the principles of profit maximization and utility discourage looking at institutes and do not allow individuals to assess their role in everyday economic activity. All these ideas do not explain anything; they simply create further difficulties. Bowles (2004) rightly believes that the establishment of institutes depends on the interests of authority groups and associations. However, this view does not provide much of an explanation and some issues remain unanswered. Why do institution changes occur, causing inconvenience and difficulties for the authorities? Why are there democratic institutes that expect a government to be able to be superseded and for it to be responsible for the result of a policy that is being implemented? It 
is most likely that North (2005) has made the most progress to date in studying the motives that people are guided by when creating institutes. In his opinion people have always sought to eliminate uncertainty, which, since ancient times, has created difficulties for the development of human society. Uniting in tribes or following the orders of a feudal lord, king or pharaoh people found protection from foreign enemies and guaranteed themselves a minimum level of benefits. Serfdom is an effective contract between a serf and landowner: protection in return for the labour of serfs on the landowner's land (North and Thomas, 1973). In this way the serfs reduced their risks of being killed or dying of hunger. However, as labour tools became more advanced and productivity increased, the moment came when serfs were able to feed themselves and their families and they also had a small amount of funds for their own protection. Serfs began to need laws that established their rights and enabled them to enjoy the protection of the police and other security agencies of the government. In the cities these processes occurred even faster. In the smallest municipality there were many literate clerks who for an additional fee would gladly provide legal services and tried to protect ordinary citizens and their property. This is how capitalistic institutes came about. Marine trading began to flourish when merchant risks were minimized due the arrival of insurance companies (Heiner, 1983). North's idea is worth considering, but it contradicts modern economic concepts and is not supported by observable facts. Modern science believes that individuals seek to maximise utility. If one assumes that they also seek to minimise uncertainty, then we can boldly go further and argue that in each individual case people maximise and minimise the most varied indicators imaginable. A gardener maximises the number of apples grown, a taxi driver - the number of passengers, a builder - the total height of all buildings built and a doctor minimises the number of patients. Furthermore, a person does not always seek to reduce uncertainty. Very often people do the opposite. In choosing corporate ownership and creating exchanges, people significantly increased their risks of losing ownership and money. For what reason? The arrival of insurance companies led to the redistribution of risks from certain people to others. But the risks never went away. All of these difficulties with the definition of human motives are associated with doubt and the lack of transparency of such an economic concept as "utility", which, according to Coase (1988) "plays a part [in economic theory] similar to that of the ether in physics". In my opinion we should have long ago substituted the principle of maximization of utility for the principle of maximization of profit because any consumer is, first and foremost, a producer. In order to consume, a person has to produce something to exchange or to use for their own personal consumption. A person is also a producer when they are working in a firm. They go there not at gunpoint, but because their pay there is higher than if they were working on their own. Nowadays, the boundless faith that firms have power over employees seems increasingly doubtful. The argument that capital hires labour (Bowles, 2004; Brown, Falk and Fehr, 2002), and not the other way round, is easy to doubt. It is enough to look at the list of the largest companies in the world. Many of them were created through the labour and efforts of enthusiasts without capital from third parties, at the initial stage at least. After the first major successes of these companies, capital owners queued up in order to gain a share of the ownership in the new and promising business. From that moment on labour hired capital and capital was subject to all its demands. All the consumer goods for the individual are resources that are used by them in order to produce. People always 
maximise profit, both when they are participating in the production process and when they go to the shopping centre. If a person seeks to maximise profit then obviously the amount of transaction costs of exchange will become priority. Transaction costs lower profit and therefore in order to evaluate the quality of laws and institutes, the main criterion is how much the institutes are able to reduce the person's costs and increase profit. It is not surprising that North, using such a dubious premise, finally came to the terrible conclusion that sometimes dictators are able to create effective institutes. I would add that it is not sometimes, if we follow North's logic, but always. A dictator is always able to deal more effectively with uncertainty and react faster than a dispersed crowd of lone selfish individuals. If we assume that individuals maximise profit then it will be reasonable to suppose that through voting they achieve a more effective solution than a dictator. A certain law may bring profit to certain groups of individuals, and take profit away from others. The law is approved if the majority receives profit. This means that the total profit will be greater in the case of the approval of the law than in the case of its rejection. Since profit is an indicator of the effectiveness of the producer, the approved law will raise the level of production of goods and services. The dictator, however, is not able to assess the profits of all citizens, he has nowhere to get this information and, what is more, this information is hidden from him carefully. This is why democracies demonstrate impressive progress and dictator regimes die out like mammoths. But we will talk about this a little later on.

\subsection{Market Failure}

Most of the definitions of market "imperfection" or "failure" known today cannot be regarded as satisfactory. Weimar and Vining (1992) believe that market "imperfection" occurs when the pursuit of private interests does not lead to an efficient use of society's resources or a fair distribution of society's goods. This immediately raises the issue of the criteria for efficiency and fairness. Who will determine the level of inefficiency and, most importantly, how? Let us suppose that through voting it is somehow possible to solve these problems. The government intervenes in the market process and a miracle takes place: the production of certain goods and services increases. But it could also increase without intervention and the growth could be even more. The problem is that after intervention, nobody will ever be $100 \%$ certain that the economy has become more efficient than it could have been. We also need to consider the situation in other branches of the economy because an increase in production in certain branches may have a negative effect on the development of another sector. And if we take into consideration that the words "state intervention" are a mask for the words "bureaucratic intervention", then a positive outcome from the intervention should be thought of as very unlikely. There are countless examples of questionable interventions and if we mention them all, this article may easily turn into an entire book. So as not to bore the reader with numerous attempts at defining the concept of "market imperfection" I will give the most appropriate of them. Ledyard (1987) links market "failures" with a so-called market incompleteness, which in turn is linked to a lack of perfect competition. Arrow (1969) believes that market "failures" occur when there is no market for certain goods and they do not have a fixed price. Both authors are trying to say the following: market "failures" are not a failure in the market mechanism, but rather the lack of a market. The only valid method of treatment is to create a 
market rather than trying to correct it. There is no market with pure air and unpolluted oceans and seas. There are many reasons for this which we will discuss later on.

\subsection{Coase Theorem}

Why were none of the attempts to formulate the Coase Theorem successful? Because what Coase feared most happened. Most economists were so fascinated by the world of zero transaction costs that they tried to formulate a certain rule for this unreal world as a theorem. In a non-existent world there can only be a fairytale hero whose only use is to entertain a bored audience. If economists so love to compare transaction costs with physical friction then let us use this analogy. After physicists established that any object is prevented from moving in a straight line for an indefinite period of time by the force of friction, they focused all their efforts on scrupulously studying this phenomenon. Using an experimental approach, scientists determined the friction coefficients for a great number of pairs of objects: for wood and metal, for glass and plastic, for rubber and paper and for many other materials. They found that the force of friction was much less with rolling than with sliding. In order to reduce friction they began to use various lubricants and structures. Rolling and slide bearings appeared, as well as tapered and spherical ball bearings in various combinations. We see the real, not imaginary, results every day. Vehicles are driven about towns, trains and aeroplanes travel between cities and satellites and space stations spin in space orbits. Therefore, in order to achieve success we should not stay in the fairytale world for too long, but hastily return to the real world of imperfect competition and transaction costs. I will also follow this advice. Let us discuss the practical conclusions that follow from the Coase Theorem.

\section{Political and Economic Institutes Yesterday, Today and Tomorrow}

\subsection{Institutes and Economic Profit}

Both consumers and producers seek to maximise their profit. There is no difference between consumers and producers. What is more, everybody is both a producer and a consumer. We consume in order to produce and produce in order to consume. 6,000-10,000 years ago when there was no goods exchange between people, they only consumed what they obtained or produced. There was no difference between the processes of production and consumption, everything that was produced was consumed. There have been no fundamental changes since these times. Of course, it became possible to exchange goods and services, money and inflation appeared, the processes of production and consumption became more complex and savings and investments arrived. People became more intelligent and developed many complex labour tools, but they still seek to earn a profit. In the past they obtained profit using a stone axe and a wooden spear, and now they use computers and sophisticated machine tools for the same purpose. In medieval times peasant families did not divide up their costs into consumer costs and production costs. Food, clothing, spades and ploughs were general costs for a family. If at the end of the year the family had more food, clothing, spades and ploughs then that meant that they had made a profit. In the winter when less work was required on the land, members of the family processed wool or produced baize. They rather quickly discovered that they could get profit by exchanging their goods for the goods of another peasant or craftsman. Wicker baskets began to be exchanged for horseshoes, horseshoes for bread, bread for pottery goods. The first 
merchants arrived in the villages bringing goods from town which were exchanged for peasant goods. The merchants reduced the transaction costs of exchange, a peasant did not have to travel to the town and build complex goods exchange chains. The simple goods exchange lasted for a very long time and only the 19th century became the century when money triumphed (Braudel, 2011), which greatly reduced transaction costs of exchange. The profits of peasants increased, as did production, roads appeared, everything became safer. And one fine day a peasant discovered that his income would be greater if he himself, or in partnership with a neighbour, went to the nearest market that could be reached within one day (the distance between towns and cities in Europe was usually no more than 40 kilometers). The owners of the city or the municipal authorities obtained a sizeable profit from the market and therefore the markets were a fairly safe place. All business disputes and conflicts were resolved through fair or market courts that existed right up until the end of the 19th century. Transaction costs of exchange decreased, throughout the entire history of humankind they have reduced continuously. It was for this very reason that the number of exchanges increased constantly and more and more new products were included in this process. Each exchange brought profit to the participants of the transaction; otherwise the transaction itself would not have taken place. An increase in profit meant that the production of goods and services could be expanded and therefore the reduction of transaction costs was accompanied by economic growth. This is a good point to stop at. Why does profit always cause economic growth?

\subsection{Profit and Economic Growth}

Since the times of Adam Smith it has been well known that people, in pursuit of their own personal interests, contribute to the prosperity of society as a whole. We can say many wise words about investments, profit and the expansion of production, but one question remains. What connection is there between profit and economic growth? Why do people, in seeking to maximise profit, maximise economic growth? The answer is very simple - because profit is economic growth. The complexity and the number of modern exchanges cloud our understanding of simple things, but 500 or 1,000 years ago even the most uneducated peasant would, without thinking, put an equal sign between profit and economic growth. In the times of simple goods exchange there was no difference between these concepts, they were synonyms. Profit could only be materialised in the form of additionally produced goods. For any person, any amount of additional goods meant profit. If in a certain closed economy the profits and losses of all people are added together, the result will be exactly equal to the value of the additionally produced goods (Bilych, 2012). In an economy where money is used for exchanges and there is inflation, the equation will be satisfied for nominal values of profit and economic growth. Incidentally, this equation knocks down Marx's capitalist exploitation structure like a house of cards. Exploitation is not possible in a competitive market economy or is very difficult at any rate. In a centralised economy, however, it flourishes because a great deal of officials and representatives of security agencies, who do not produce anything and who control everything and everyone, receive a salary that is above their marginal product of labour. For everybody else their salaries are lower than their marginal product. This is the answer to North's (2005) assumption on the high level of efficiency of economic and political institutes under the conditions of a dictatorship. Through an incredible amount of effort the Soviet Union 
launched the first-ever satellite into the Earth's orbit, but it was other countries that made commercial use of this achievement and earned the profit. Without a desire for profit it is not possible to have effective institutes or continued economic growth. Under a dictatorship, transactional costs of exchange are immense, but the desire to earn profit does not go away, despite the fact that the word "profit" itself has a dubious undertone. The queue for a scarce commodity is bought and sold, many services are provided only through bribes or another service. Economies such as these will inevitably degrade because the main motive of human activity within them - the desire for profit - is weakened. However the very first positive political and economic changes bring about a real flourish in trading. Everything is traded by everybody. Institutes of economic exchange are created because even with the most modest production they generate profit straight away.

Why do different countries have a distinct difference in long-term rates of economic growth? Why from 1960 to 2000 did the Democratic Republic of Congo, Niger, Mozambique, Nigeria and Zambia have negative growth rates? Why in China, Ireland and Botswana over the same period of time were growth rates higher than in the US or England? As stated by Barro and Sala-i-Martin (2004), if we can figure out which government political decisions might have even the slightest effect on long-term growth rates, then we will be able to make a much greater contribution to improving standards of living than has ever been done throughout the history of macroeconomic analysis of countercyclical policy and the fine-tuning of the economy. Considering everything that has been mentioned above on transaction costs we can now understand the reasons for such different economic results. Let us examine the process of implementing technological innovations in different economies with the example of implementing voice and video communication via the Internet with Skype. Any innovation will be implemented if it is able to generate profit, the amount of which, of course, depends on the amount of transaction costs of exchange. Suppose that in the US where transaction costs are low, Skype technology lowers economic costs by $2 \%$ over a certain period of time. Consequently, companies' profits increase $2 \%$ and the additional economic growth is also $2 \%$. In Nigeria, by no means all of the population has Internet access. Therefore, new technology will only be implemented in large cities and even there it will mainly be used only in order to reduce costs for international and intercity negotiations. This means that profits and economic growth will only increase slightly, perhaps by $0.5 \%$. It is most likely that local officials with corruption interests in branches of traditional means of communication will take certain steps to protect their income. There will be decrees, permits and new laws that will make implementing innovation much more difficult. It may indeed be the case that the actions of officials will enable tariffs to be raised for the services of ordinary telephone companies. These actions will increase the costs of all companies, let us suppose by $1 \%$ on average. As a result, the real income of citizens in Nigeria will decrease 0.5\%. In Botswana events may take a different turn. The country's government, aware of the importance for national producers and the general public of a cheaper form of communication, will take measures to improve the economic climate on the communications service market. The procedures for the registration of new companies may be made simpler, taxes lowered, licences withdrawn. Of course, these measures will not be able to reduce transaction costs to the level of the most developed countries, but they will significantly increase the profits of many companies. This will result in 
the overall transaction costs in the country decreasing 4\%. As Skype technology enables labour productivity to be increased by $2 \%$, the overall economic growth in Botswana will be $6 \%$ and the country will be higher than the US in terms of this indicator. This means that between Botswana and the US there will be a so-called economic convergence (Barro and Sala-i-Martin, 2004). The difference between the levels of economic development and per capita income in these countries will decrease. The difference between per capita incomes in the US and Nigeria and also in Botswana and Nigeria will increase. The levels of economic development of the countries depend, to a large extent, on the amount of transaction costs and the size of economic growth depends on the size of the decrease in transaction costs. If at any moment in time transaction costs disappeared, all the global economies would demonstrate absolute convergence, the incomes of all the people on the planet would be the same. A reduction in transaction costs of exchange is a key factor for successful development. The main motive for economic policy should be a decrease in transaction costs and an increase in the profit of producers and consumers. All other objectives of action taken by officials should be considered secondary.

\subsection{Property Rights}

Demsetz (1967) was right when he argued that private ownership of land came about on the basis of common ownership at a time when land had become a rather valuable factor. And it became a valuable factor when the profit from its use exceeded the costs to protect it from capture by others. Costs for protection are certainly transaction costs of exchange because without protection of ownership rights, the act of exchange itself is not possible. The first real owners of land were pharaohs, kings, the Church and important feudal lords who owned huge areas of fields and pastures. The income from these properties enabled them to maintain a large, well-equipped army and also many guards and supervisors. Governments became stronger, laws improved and the labour productivity increased. After a while, a peasant was able to rent a plot of land for himself or buy it from the landowner. This was beneficial to both parties. The landowner no longer needed to maintain an extensive body of supervisors and guards. Aside from this, the constant improvement of technologies for cultivating and harvesting crops required constant learning and hard work. The development of market relations meant that price trends had to be followed for different crops and goods made by a town's artisans. Smaller producers were able to deal more effectively with this. In countries where political groups in power did not particularly object to redistribution of land in favour of smaller owners, the laws secured these rights of the new owners. This is how private ownership of land appeared in the advanced countries of Europe. The forest, the horse, the mill, the loom, the spade and the plough all became private property in exactly the same way. Any factor of production or consumer goods became property at the moment in time when the profit from their use became greater than the costs associated with their ownership. The difference between the profit and all the costs determined and still determines the price for the product. Nobody pays more for a product than the profit they will receive from its use. A plant or a factory is worth exactly as much as the profit the asset is able to generate until its complete physical and moral deterioration. Profit is the most important economic category. Profit determines the prices for any product, the total profit from the use of all products determines the economic 
growth in an economy (further information on this in: Bilych, 2012). The price of a product determines the value that the owner of the product will receive. Therefore, a product with a price is private property. And therefore the value of transaction costs becomes extremely important. The increase in labour productivity and the decrease in transaction costs are the main reasons for humanity's transition from primitive society to feudalism, from feudalism to capitalism and from capitalism to something else.

\section{Market "Failures" or No Market?}

\subsection{Reasons for the Lack of a Market}

Arrow (1969) was, of course, right when he argued that market "failures" are linked to the lack of a market. There is no market for a certain product when there is no price for the product. This means that the transaction costs of exchange are greater than the profit from its use or exchange for another product. This means that we have not learnt how to use the product in a productive enough manner. Domestic and industrial waste will be normal waste until we learn how to use them in such a way that the profit generated from them is greater than the costs to collect and process them. As soon as profit is generated, a price will immediately be formed for the product. It will be able to be bought and sold and there will be a market for waste. Nobody will even think of throwing it into the river or polluting the air with it because they will be a valuable resource that can be used to obtain profit. Should the government intervene in the situation or not, when there is no market for a certain product or it is clearly deficient? What can officials do in this case? Any intervention usually creates additional transaction costs, but these costs are not distributed equally between different groups of economic agents. The market therefore ends up being further from its ideal state than it was before the intervention. The market for a certain resource cannot function normally if people cannot generate profit from the resource, people will not have enough knowledge or ability. What can officials do to help? Nothing. They do not have enough knowledge or ability either. Markets for insurance services or used cars, for example, suffer from the drawback associated with the unequal distribution of information between parties to a transaction. Any official will have less information than any party to the transaction. Therefore intervention is only likely to make matters worse.

Many people associate the occurrence of market failure with the undesirable effect of certain economic agents on others, which was not covered by a contract (for example: Pigou, 1920). This effect may last for a relatively long time and bring a loss to one party of the conflict and profit to the other party. According to Stigler (1966), there is a difference between social and private costs. Many people believe that with these words, any responsible person should blush with outrage and immediately demand to intervene in the situation. However, the economy is different to other types of human activity because feelings of fairness and equality in it very often lead to fatal errors. This is because normal economic interaction may end with an agreement that improves the situation for all parties to a transaction. As mentioned already, any exchange of goods or rights brings profit to both parties. Otherwise an agreement would not be reached. If a third party to the transaction appears - the government, or rather a government official with a strong passion for justice - then there will be no need for the parties to reach an agreement. For an official one party to a conflict is usually the victim of another and therefore 
one of the parties to a conflict must be punished. If there is a criminal they must be given the punishment they deserve. None of the parties will try to conclude further agreements. But for the optimum solution, information is not enough for an official. The main problem is that the official will never, under any circumstances, be able to obtain a sufficient amount of information. The parties to a transaction have the most accurate information, but they are interested in exaggerating their losses and understating their profits. In this case they will also act rationally, they aim to maximise their profit. Suppose that a certain producer is polluting the air and people whose homes are situated in the vicinity are suffering the effects. Neither of the parties to the conflict has the right to release harmful gases into the atmosphere, but the producer is already exercising this right. Therefore residents must offer him a certain amount of money enabling him to improve his situation. Why do they not do this? Because the transaction costs of an agreement between them may be very high and are greater than the profit that may be earned. They may not be able to accurately evaluate their costs associated with air pollution. The latter statement seems to me to be the most likely. Nowadays we know very little about the real consequences of atmospheric pollution. We do not even know the exact causes of global warming. Some people believe that the main cause of global warming is the emission of greenhouse gases and others argue that it is a consequence of cyclical climate changes. We do not know enough about it. In this situation, counting on an intelligent government official to come and make the right decision would be foolish and naïve. It is foolish and naïve to believe that as a result of a producer paying compensation to the residents in neighbouring homes, the production of undesirable goods will decrease and the production of other goods will increase. The requirement for the payment of compensation is due to officials longing to win more votes from the electorate. This is generally why producers pay compensation and consumers receive it. Compensation causes a reduction in the production of goods and an increase in their price. Producers always seek to cover their losses. The price will increase until the additional revenue is exactly equal to the losses incurred. Therefore consumers will be forced to return all compensation received back to the producer. There will be no positive economic changes. The only result of the intervention will be an increase in inflation and a decrease in the production of goods, which will affect everybody. This will not be in vain if it reminds us of our foolish arrogance. Buchanan (1979) rightly noted that government "failures" happen more often than market "failures". Dangerous socialistic views are hidden behind concerns for wellbeing. It is naïve to believe that an ideal can be reached through them. On the contrary, they will most likely not only take us infinitely far away from the ideal, but will also destroy everything useful that has already been put in place.

\subsection{Problems of Economic Interaction}

Ask yourself a very simple question: do you know of many economic events and occurrences that would concern the interests of a very narrow circle of people? I do not know of any such events or occurrences. Any production process generates waste, any additional purchase of a product increases the demand for it and its price, instead of building a skyscraper you could plant a garden and the summer house that I bought took away from someone else the opportunity of having it. Any action and any agreement have an effect on an infinitely high number of economic agents. Why is it that in certain cases we worry about the effects of 
economic actions and economic exchanges on others and in other cases we ignore them? Why have we decided that a firm that is a source of pollution does not take into consideration the damage it causes? Firms sometimes install treatment facilities voluntarily. It does not matter at all if they do this under the pressure of non-government organisations or if they do it in order to have a good reputation. A market is the best method for finding effective solutions. A market where everybody participates in voting with money and a market that takes into consideration the opinions of all without following just one opinion, even if it is the opinion of a very well-respected expert. Not too long ago the Food and Agriculture Organisation of the United Nations came to a sensational conclusion on the extreme damage that cows cause to the environment. Cows bring more damage to the Earth's environment than all forms of transport put together. The cow population on the Earth today is responsible for producing $18 \%$ of all greenhouse gases in the world. Pigou believes that farmers who rear cows should be made to pay tax. The price of milk does not account for this environmental damage, therefore it is being sold for less than it should be. Producers of chickens, sheep, pork and goats all suffer the effects. Funnily enough nobody sees or hears crowds of officials outside farmers' gates demanding that justice be restored. Nobody will ever see them there because it would be dangerous for them, they could lose votes and the trust of the public. That is much more dangerous than extorting producers of tobacco, hamburgers, strong alcoholic beverages or chemical fertilizers. Some fans of figures calculated that in order to compensate the calories lost during a walk, the average person would need to drink $420 \mathrm{ml}$ (three quarters of a pint) of milk, during the production of which $1.2 \mathrm{~kg}$ of carbon dioxide is released into the atmosphere. This is greater than the emission of carbon dioxide by a car when travelling for the same distance as the walk. It would therefore be logical to tax all pedestrians. All of this is not serious of course. If we are talking seriously then the main conclusion is that it is time that many officials and economists stopped thinking of themselves as the smartest on the planet. People are not stupid; they take into consideration all available information and carry out actions based on this. Yes, they make mistakes. Yes, they do not always behave rationally all of the time. But this is the world that we live in. In order to be convinced of the damage and impracticability of socialist ideas, all you have to do is look at the history of the Soviet Union or the current conditions in North Korea (Acemoglu, Johnson and Robinson, 2005). By acting on the strong desire to achieve fairness and build a heaven on Earth, we can only bring sadness and suffering. The road to hell is paved with good intentions.

\subsection{Monopolies}

Most economists believe that monopolies exist because of incompleteness on the market. Today, it is widely accepted that monopolies occur in branches of the economy where the optimum sizes of firms must be relatively large. In these branches there are decreasing average costs and therefore a monopoly is the most effective form of organisation in this case. This means that a battle with monopolies is a battle against efficiency. It feels as if our knowledge has no influence whatsoever on our conscience. And this is most likely the result of a serious ailment. Perhaps many of us ought to pay more attention to our mental health and not battling with monopolies. Monopolies, duopolies and oligopolies are not as bad as followers of socialist ideas would have us believe. I would like to highlight the splendid and high-quality work of 
McGee (1958), in which he analyses the activity of the company Standard Oil and its judicial trial. The main conclusion drawn from this work is that a company with market authority incurs the greatest losses from predatory pricing and unfair competition. In my opinion, Baumol (1982) made a revolution in economic science when he stated that monopolies, duopolies and oligopolies can achieve the same results as firms under conditions of perfect competition. The only condition necessary for this is absolutely free access to and exit from the branch. I believe that this condition is superfluous. Baumol believes that monopolies feel considerable competitive pressure from firms that, under certain conditions, may enter a branch market. Their signal for entry comes when the price of a product goes above the marginal costs for its production. In this case firms may take advantage of the "hit and run" tactic. Upon entering the market they establish a price slightly lower than the monopolist, but higher than the marginal costs. After selling their goods they will have profit and will be able to safely leave the branch. The monopolist, expecting an entry, will fear establishing prices above marginal costs. The only obstacle to this remarkable conclusion is the fixed cost of entry. It seems to me that this last statement sounds unconvincing. The monopolist has no advantages over other producers. The monopolist also incurs losses due to entry into the branch. It does not matter at all when it happened. Naturally, these costs will inevitably be included as part of the overall production costs. Therefore the overall costs of the monopolist and their possible competitors are in no way different; the price set by the monopolist cannot be lower than competitors. Baumol's efforts were not appreciated. Today, monopolists and large companies continue, as they did 100 years ago, to feel pressure from society and the authorities. They are still considered to be the cause of all troubles and misfortunes. Monopolies are divided up; they are shown what to produce and where they should not interfere. After this, everybody looks back on the work done and thinks that the production of goods and services has increased and the world has become much more perfect.

Imagine a lone island where there is a single, absolute monopolist who produces everything that the residents require. How can this monopolist make use of their market authority? Can they set prices for goods that will be higher than the marginal costs of production for the goods item? Let us try to answer these questions. Each month the monopolist sells all of the goods produced and has revenue equal to the total payment of the workers. All the residents work at the only company on the island and buy the goods produced by the monopolist. There are no other enterprises or other products on the island. If the owner of the company attempts to reduce costs, then their revenue will decrease by the same amount. The cost of goods is equal to the cost of labour. Marginal costs of production are equal to the price of the goods. The only owner on the island is as dependent upon the workers as they are upon the owner. Are exploitation or other forms of market imperfections possible under such circumstances? Yes, because there is no competitive market. The owner of the monopoly may stuff themselves with all of the products manufactured by the company and consume any amount of goods, increase the number of guards and supervisors, increase the number of police workers and military staff who do not produce anything useful. Therefore the costs on the island will not necessarily be the same as the marginal product of labour. It is very possible that certain residents of the island will receive less than their labour is worth and others will receive more. The efficiency of the enterprise cannot be very high. But even in an absolute monopoly the sole owner will seek to 
enhance the production process and increase labour productivity. This is the only way to improve wealth. This kind of economy is reminiscent of the centralised economy of the USSR or a feudal estate. However, even economies such as these develop slowly, gradually raising their GDP and standard of living. Everything will change on our island, however, if another producer appears. Competition will not allow the owners to infinitely expand their personal consumption and spend funds in an unproductive way. When there is competition, the main motive for action is to maximise profit. Whoever has the highest profit produces goods at a faster rate and is then able to reduce the price for them. This is when technical innovations and implementing the latest methods of management become essential for survival. The word "efficiency" becomes the main slogan of economic life. In these kinds of economies the increase in GDP is considerably higher, the laws are more liberal and the institutes are more effective. Monopolies in certain branches do not pose a serious threat because, in spite of everything, they are constantly under pressure of competition. Monopolies that were not created by officials themselves represent a market solution aimed at increasing market effectiveness. Monopolies and the lack of markets for certain goods are as common and natural in our lives as hills and mountains are on the horizon.

\section{The Coase Theorem and the Real World}

It seems as if it would be better for everybody if Coase did not mention a world with zero transaction costs at all in his work. Perhaps it would be possible to avoid unnecessary disputes and the efforts of researchers would be targeted at discussing transaction costs of exchange and not discussing a make-believe world. However, it is more likely that given the obsession of many economists with the world of perfect competition and universal rationality, nothing would change. What is it that so attracts us about the world of zero transaction costs? In this world any knowledge is readily available, there are no borders between states, everybody receives equal profit and equal salary for their labour and there are no government officials and no taxes. It is a world of equality, fellowship and sustained economic growth. This is what explains our love for this wonderful world. But there is no practical sense in infinitely marvelling at a certain ideal. Something has to be done to achieve it. A similar thing happens when economists discuss problems concerning people's irrational behaviour. An overwhelming number of people seek to increase their profit and raise their own personal wealth and their family's standard of living. At the same time there are people who despise profit, success and wealth. It is their legal right. Nobody should judge them or demand that they change their attitudes or behaviour. The economy will not start producing cars and constructing buildings for them. The production of goods and services will be less than it could be. This is no cause to start panicking and tearing our hair out. Every effort must be spent on helping those who are seeking to be free of starvation, overcome sickness, obtain a property, provide education for their children and increase their own personal consumption. We should not spend too long in a non-existent world; it is more interesting and useful to study the real world. Let us follow this advice and discuss the costs of exchange in the real world.

\subsection{Changes in Transaction Costs}

Transaction costs of exchange have, throughout the history of humanity, tended to decrease. 


\section{MInstitute ${ }^{\text {Mank }}$}

Business and Economic Research

ISSN 2162-4860

2013, Vol. 3, No. 1

There were periods in the history of certain countries and regions when costs of exchange for a long time remained unchanged or increased. After the socialist revolution in Russia in 1917 the rights of private ownership of production facilities were abolished and political rights were considerably affected. These changes resulted in a steep increase in transaction costs of exchange. Without rights of ownership exchange becomes a serious problem. But even under these conditions people found a way out of the situation. Throughout the time of Soviet power there was a flourishing black market for goods and services where people could buy goods in short supply, receive good quality medical care or get into a prestigious university. In the 1970's and 1980's, the black market in the USSR reached such a height that high party positions were bought and sold and it was even possible to buy the title of Hero of Socialist Labour. The economic achievements of the Soviet Union were greatly overestimated in the past and continue to be overestimated now. The country did, of course, produce a lot of concrete and bricks and smelted lots of iron and steel. However, concrete was poured into useless foundations, giant monuments were built from brick, steel and iron were used in the heaviest machinery and vehicles in the world and microelectronics products amazed everybody with their incredible sizes. The shops did not have enough food, but there were plenty of metal buckets and basins. Throughout the entire period of Soviet power public income was low. The main aim of any economic activity was never achieved. The experiment ended 70 years later with empty shelves in the shops and a terrible political and economic crisis. Perestroika took place under the banner of freedom and restoration of private rights of ownership. In other words, the requirement of reducing transaction costs was supported by the absolute majority of the population. However, history does not always develop in a linear fashion. The serious and complex reforms changed the mood in the society and at the beginning of the $21^{\text {st }}$ century a large portion of the population took happily to the increase in government control and the reduction of private ownership rights. It is clear that a policy such as this cannot continue forever, new economic and political reforms are not far off. They will once again take place under the banner of freedom and restoration of economic and political rights. We can recall both the increased government control and the dramatic increase in taxes in Europe after the First World War, which played an important role in the development of fascist regimes in certain countries and heightened negative trends during the Great Depression. We can recall less significant events. For example, the establishment of state trading councils in Ghana, Nigeria and Zambia caused irreparable damage to the development of agricultural production in these countries (Bates, 1981). There are many such examples. However, if we look at a longer period of human history, trends for reductions in transaction costs do not raise any concerns. The development of communication facilities, the explosive growth of information technologies, the expansion of the Internet, the reduction in transport costs and the improvement of the judicial system all significantly lowered exchange costs. In medieval times, a peasant made a few dozen acts of exchange per month at the very best. Nowadays we make hundreds of sales and purchases in supermarkets, shops and at the workplace on a daily basis. It is becoming increasingly common for us to not even have to leave our own homes or offices in order to buy or sell goods and services. We can easily obtain any information using a computer. 100 years ago, in order to conclude a business agreement people had to make a great deal of effort and spend a lot of time and money. Nowadays we can conclude a contract very quickly 
with minimal costs and without having to leave the office. We now no longer have to meet with our partners in person; we can obtain any information we need by typing a few words onto a computer keyboard. There is, however, also a reverse trend. Officials do not want to give up their positions without a fight, and, what is more, they are assuming the offensive. At the end of the $19^{\text {th }}$ century government costs were only a small portion of the GDP. Today in developed countries this figure is closer to $50 \%$ and in some countries it is higher than this. There are continued attempts to regulate economic activity, transfer resources from one branch to another, limit the activity of banks and investment companies and introduce additional taxes for exchange transactions. Huge sums are spent on defence and healthcare and state pension programmes are expanding. Figure 1 shows the transaction sector of the US from 1870 to 2000 . Of course, the growth of this sector does not mean that transaction costs are increasing. To suggest otherwise would be the same as stating that the costs on education are thought to be increasing in a particular country because the population is becoming less intelligent. The transaction sector includes banking, financial services, wholesale and retail trading and a considerable proportion of public expenditure. In every company there are accountants, lawyers and other employees whose job it is to reduce costs on exchange operations in the complex world of the ever-growing number of impersonal exchanges (North, 2005). The increase in the number of firms and establishments in the US demonstrates a slight reduction in transaction costs (Figure 2). Furthermore, the number of employees involved in production is increasing at an even faster rate. As a result of this, the sizes of firms have slightly increased recently and they have expanded their workforce. This was predicted by Coase. He argued that a decrease in transaction costs of external exchanges did not necessarily have to lead to a decrease in the sizes of firms because management costs can also go down. Scientific and technological advances do not only lower the external costs of firms, but they also lower their internal costs. It is difficult to define the general trends of the last 20-30 years, but one would very much hope that this and other issues will be resolved by economists in the near future.

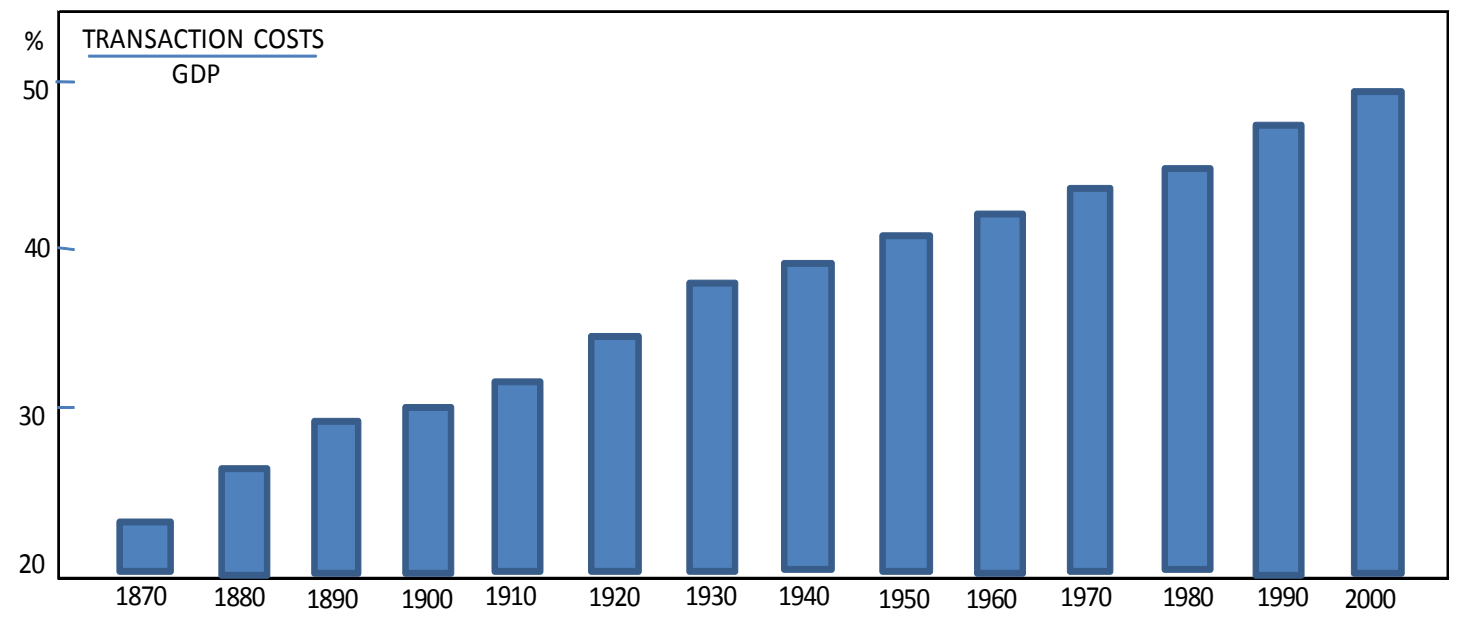

Source: North D.C. Understanding the Process of Economic Change. Princeton University Press. 2005.

Figure 1. The share of the transaction sector in the GDP of the US (1870-2000) 


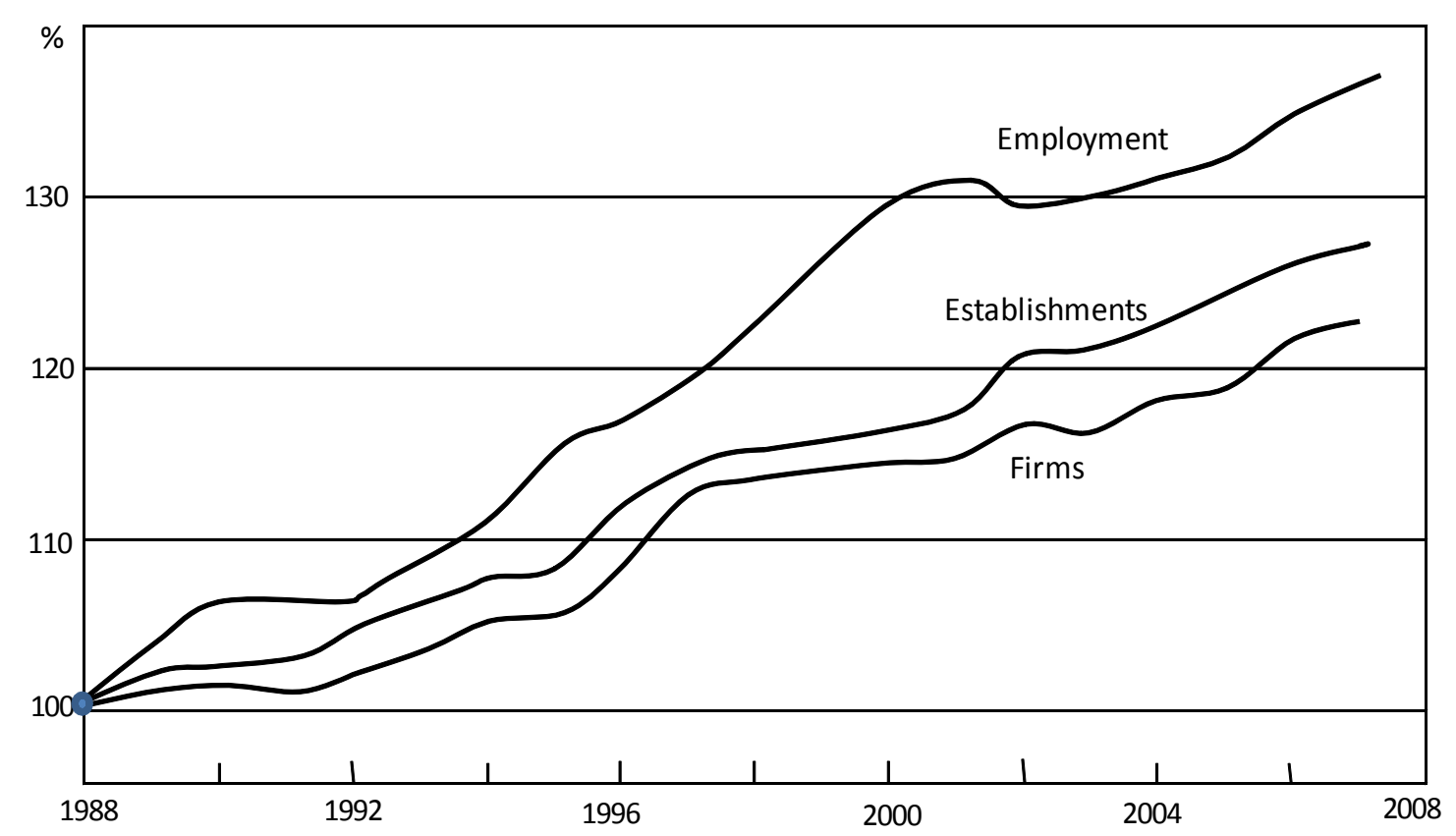

Source: U.S. Department of Commerce (www.census.gov)

Figure 2. Number of firms, number of establishments, total number of workers in the US (1988-2007)

\subsection{Formulating the Coase Theorem}

The time has come to discuss the famous Coase Theorem. In order to attempt to properly formulate this theorem, we will have to take leave from an ideal world and move to a world where not everybody behaves rationally and people who do behave rationally come up against many obstacles in achieving their goals. What happens as a result of exchange in the real world? Why do people or organisations try to close a deal and make an exchange? The answer is obvious: people seek to earn profit. Without profit there would be no sense in concluding any agreement and carrying out a transaction. What does this mean? It means something very simple and extremely important. An exchange results in additional profit. A consumer product or a certain resource goes to the person who is able to earn a higher profit than the previous owner of that product or resource. The parties to the exchange share the additional profit between themselves. The trading is beneficial to all and nobody loses out in this process. As mentioned previously, any product is a resource and the price of a resource equals its marginal product. However, from the same resource, different producers and different individuals receive slightly different marginal products. The amount of the marginal product depends on their capabilities, education and whether there are other resources. For this reason the price is determined by the average marginal product. Efficient owners of a resource earn profit and inefficient owners make losses. Following an exchange, a resource is transferred to a more efficient owner who receives more of a product from the resource than the previous owner. This brings economic growth. Every exchange of goods, services or rights increases the production of goods and services. In this way, profit, which is the lucrative aim of any individual, turns into economic growth and enables the whole society to flourish. As mentioned 
earlier, profit and economic growth are synonyms. The total profit of all consumers and producers is the same as the economic growth (Bilych, 2012). After all of this, it becomes clear that any reduction in transaction costs of exchange will increase the profit of firms and individuals and also raise the overall level of economic growth. In his example with the rancher and the farmer, Coase, as in many of his other examples, uses the words benefit, damage, marginal benefit and marginal damage. Consciously or not, he avoids the words profit, losses, marginal profit and marginal losses. This was most likely due to a very strange division that is still in force to the present day, of all economic subjects into consumers and producers. Some maximise utility and others maximise profit. A division such as this is capable of driving anybody into insanity. When working in the office we have to think about profit, but at lunchtime, when we go to the café, we have to think about utility. What happens if we get everything mixed up? Even if we do not mix anything up, in the evening in the shopping centre, as we buy a computer, we might be in for a shock. This shock will be from the exertion of our brains trying to solve an impossible problem. What should we maximise? We can use a computer for entertainment and also to compile a report for our manager. Using the principle of maximisation of profit would help Coase to simplify his presentation of the material and it would help his followers to avoid countless mistakes when discussing problems concerning the optimum distribution of different rights. Many situations are discussed in economic literature where one of the parties to a conflict behaves passively and does not try to maximise anything. A situation such as this is highly rare in the real world. Therefore, the conclusions of the authors of the textbook or article are wrong. For example, there is a source of harmful emissions and there is an affected party, the damage from pollution is $\$ 125,000$, the cost of installing equipment to prevent pollution is $\$ 100,000$. The pollution is "overproduced". The sum of $\$ 25,000$ is the benefit that can be obtained from eliminating the harmful emissions. If the amount of transaction costs (negotiations, courts, contracts) is less than $\$ 25,000$, the measures to eliminate pollution will be taken. Otherwise there is no incentive to resolve the issue. This conclusion is wrong because it fails to take into account the desire of the affected party to maximise their profit. Let us suppose that moving to another location costs the affected party $\$ 40,000$. The affected party may demand a sum that is slightly higher than $\$ 40,000$. The other party will happily agree to this and the conflict will be resolved. The affected party not only avoids the pollution, but also receives a small amount of pocket money. If there are no transaction costs, production will decrease not by $\$ 100,000$, but by $\$ 40,000$ or a little more. Even if the transaction costs are $\$ 25,000$ or a little more, this will have no effect on the end result. In the case of the rancher and the farmer, the result of any dispute concerning a land plot depends on the amount of profit that both parties are able to earn from the plot. The plot will be used by the party that has the highest profit. All parties to the dispute will be satisfied with the result obtained. One party to the conflict will receive profit using the land plot for their own aims and the other party will receive financial compensation. More effective use of the land will lead to an increase in the production of goods. The net profit of any agreement is equal to the total profit of the traders minus their losses and minus the transaction costs of the agreement. The net profit is equal to the economic growth. The principle of maximisation of profit enables us to also analyse trading agreements between countries. In this case the rancher and the farmer are substituted by two different countries, but the principle of analysis remains the same. 
Suppose that one of the countries introduces customs duties on goods coming in from the other country. What changes after a decision such as this and how does it change? Before the introduction of customs duties trading firms of both countries drew profit from the exchange process. Otherwise they would not engage in foreign trading operations. The total profit of the trading firms in one country was approximately equal to the total profit of the firms in the other country. This is how it should be because there are no grounds to believe that the population of one country is more intelligent than the population of the other country. Specialists from different countries usually have the same level of access to knowledge, similar technologies and they are easily able to assess the quality of a product on offer. It would therefore be most reasonable to assume that the profit from the exchange of goods, services and rights is divided by the parties in half. Equality of profit means equality of economic growth. Consequently, thanks to foreign trading, the GDP in these countries increases to the same value. Customs duties are additional transaction costs for trading firms. A proportion of transactions or all transactions will be blocked. The result will depend on the amount of profit and the amount of customs duties. If all transactions are blocked then the economic growth in each of the countries will decrease to a value equal to the total profit of all national firms that participated in international trading. It this case everything is clear. If some of the firms continue trading then their profit will be lower than before by the amount of customs duties. They will most likely divide the profit in half. Investments and economic growth will decrease significantly both due to the loss of profit at the firms that refused to trade and also due to the decrease in profit at the remaining firms. Now it is time to deal with customs duties. How will they affect the development of the country that introduced them? Of course budget revenue will be less than thought at the very beginning. The country's budget will receive some additional cash flows that, after a certain period of time, will enter the economic cycle. This will cause an increase in inflation because the production of goods and services in the country will have decreased. Some economists believe that a rise in inflation will aid economy recovery and perhaps bring about a temporary increase in production. Over the last 40 years this assumption has given rise to more and more objections and doubts. Hess and Morris (1996) argue that even a slight increase in the rate of inflation will have a negative effect on economic growth regardless of the condition of the economy. Based on the results of extensive research, economists of the IMF arrived at the conclusion that if in developed countries inflation goes above $3 \%$ it will lead to a considerable slowdown of economic growth rates (Khan and Senhadji, 2001). Furthermore, many authors of publications are surprised by persistent attempts to use a rise in inflation to explain a slight economic recovery and not the other way around (Bilych, 2012). There are facts and arguments which suggest that accelerated economic growth causes a rise in inflation. But even if one agrees with the positive influence of inflation, the conclusions will still not be any more optimistic. Data available today suggest that an increase in inflation (in per cent) is much higher than the increase in values of economic growth (in per cent). If we return to our two trading countries then everything that has been mentioned demonstrates the negative effect of customs duties on both countries. It is highly possible that this effect will have a stronger impact on the economy of the country that put restrictions on foreign trading. Now is the perfect time to return to the Coase Theorem. 
Everything is now ready to formulate the Coase Theorem for the real world where transaction costs are not zero. The Coase Theorem should read approximately as follows:

A decrease in transaction costs of exchange increases economic growth. The greater this reduction is, the greater the level of economic growth.

Of course, for a more rigorous formulation we should state that after a decrease in transaction costs, economic growth will, at the very least, be less than it was before that and all other economic parameters should remain unchanged. However, I believe that for any sufficiently large economy, the initial formulation will be true. Even if a decrease in costs raises the profit for a few companies then additional investments will be made. This interpretation enables us to not only discuss the theorem in a more productive manner, but also verify it. Transaction costs and economic growth are completely normal economic indicators that can be presented using conventional figures. Therefore the validity of this kind of theorem can be verified. It is a theorem from a real world, not a dead world. Let us suppose that the use of electronic mail reduces the number of telephone calls and enables savings of $\$ 1$ on negotiations. If electronic mail is used to conclude 1,000 deals a month, for instance, the total additional profit of the parties to the deal will be $\$ 1,000$. These funds will certainly be invested. It does not matter who receives them, the consumer or the producer. Firstly, as already mentioned above, there is absolutely no difference between consumers and producers. Secondly, if the funds are allocated for the purchase of so-called consumer goods the additional funds for investment will be received by the producers of these consumer goods. In any case the $\$ 1,000$ will go towards expanding the production of goods and services. The total value of these goods and services will be $\$ 1,000$. The additional economic growth will be $\$ 1,000$. This, of course, is the nominal amount of economic growth, the real amount depends on the efficiency of the investments made. In general, the amount of inflation depends on the efficiency of the market; inflation is a measure of the inefficiency of an economy. We increasingly see high inflation in countries with market institutes that are inefficient or not efficient enough. Corruption, poverty and a high mortality rate are the result of weak institutes and imperfect laws. High costs for the exchange of goods or rights bring the level of economic growth down and in certain cases they even put it in negative. Not everything, but a great deal in our imperfect world depends on the amount of transaction costs.

\subsection{Freedom, Democracy and the Coase Theorem}

When a small street vendor in Tunisia or any other country in the world discovers that their profit could be higher if their individual rights were not limited by lots of regulations and restrictions and that laws would reduce their costs, then they wonder why they are in a situation like this. The trader understands perfectly well that the authoritarian governor and the many people surrounding him do not want any changes. The governor and the people surrounding him have control of the most important and lucrative sectors of the economy. Most active entrepreneurs will never have access to this. The lack of competition in key sectors leads to a very high level of inefficiency in the whole economy. The inability to openly express ones viewpoint, the government's pursuit of activists of non-government organisations, the destroying of any dissidence and political repression all make it impossible to publicly control 
government officials and members of the elite. The result of this is terrible and pervasive corruption. The courts are under the full control of government officials, not the public, therefore they try to protect the authorities at all costs and punish those opposed to the regime in force. Even under these conditions members of the general public find any opportunity to reduce their costs and raise their standard of living. They look for opportunities to talk with other members of the public, discuss pressing problems and make changes for the better. The cheapest and safest methods of communicating today are social networking sites. This is why social networks have become such a serious problem for many governments. Any information can be distributed and discussed in these networks. It is for this reason that in recent times government officials have been making huge efforts to make some kind of attempt to control the Internet. On December 17, 2010 mass protests were sparked in Tunisia by the public self-immolation of a street vendor who sold fruit and vegetables in a small town and whose goods had been confiscated by the authorities. Seizure of property has always been and remains the best method of extorting bribes in undemocratic countries. This method works perfectly well in controlling dissidence and also in the fight against political opponents. The people who protested in Tunisia demanded that the government put a stop to corruption, increase employment and grant more rights to the public. The authorities used force in response to this and there were victims. This resulted in even greater unrest. It did not matter how many dismissals and reshuffles there were in the highest authority structures; they were unable to alter the situation. The peak of the civil unrest, in which the president was forced to flee the country, came on January 14, 2011. Civil society in Tunisia was given a chance; the opportunity had arisen to make democratic transformations. Whether they will actually be made or not is another question. In what way is a democracy better than totalitarian regimes? What is its advantage? The advantage is that any decision is made through direct vote or public discussion. Officials cannot make any decision without the consent of the majority of the public. The free press, publicly elected representatives, non-government organisations, specialists and activists all take part in the discussion of any law. As stated by Wittman (1989), competition between different pressure groups and political parties in a democracy ensure the efficiency of political institutes and general laws. A decision is taken when the majority of society approves it. This means that the majority of the public receive a certain benefit from a new law coming into effect. In economic language this means that they receive additional profit. If the law were to be rejected this would mean that less people would receive profit. Given that total profit is equal to economic growth, a conclusion should be drawn regarding higher economic growth rates if a law is adopted. There are, of course, situations where the minority may receive a greater profit than the majority, but this is normally rare. And in the event of such situations occurring, it would be logical for the minority to offer the majority a portion of their profit. This is in fact what happens in real life when many political and economic decisions are taken. Of course, a democracy is not the ideal method for arriving at an agreement, but at present it is the most effective form of state arrangement. On the goods and services market decisions are made much more efficiently. An individual vote has a certain weighting which depends on the amount of money. A more efficient producer or consumer has more funds because his or her vote has more of an influence on the demand, the supply and the price. But this is not without its flaws: money is given in inheritance, the level of education 
depends on the income of the parents, officials take bribes and a dictator has billions in the bank. There are no ideal solutions in the real world - there are good solutions, bad solutions and very bad solutions. Democracy is a good solution for social problems; it reduces transaction costs, helps to earn profit and enables society as a whole to flourish. It is not certain that countries in which there have been so-called Arab revolutions will choose the path of democratic change. People do not always behave rationally, they sometimes make mistakes. However, democratic changes are as unavoidable as the arrival of spring. Dictatorships will die out, as did the heavy-footed dinosaurs that were not able to survive in the conditions of the ever-changing world around them.

\section{Conclusion}

Coase's introduction of the concept of transaction costs into economy analysis had a profound effect on the development of economic science in the $20^{\text {th }}$ century. Today the majority of economists agree that this effect has not only been positive, but also very beneficial. Coase's ideas are gradually becoming increasingly significant, entering many areas of economic science (as well as other areas). Only revolutionary ideas can have this kind of success. Transaction costs came into science for the first time and stayed there forever thanks to the arrival of Coase's article The Nature of the Firm in 1937. This article explains simply and clearly that the size of a firm depends on the ratio between transaction costs of exchange and management costs. Today nobody needs to be told how transaction costs of exchange and inter-firm management costs can change the "positive effect of the scale of production" into the "negative effect of the scale of production". It is clear that if the transaction costs of exchange are very high in comparison with management costs then the size of a firm may increase to the size of a state. This is the reason why in the past there were large centralised governments controlled by leaders, pharaohs or supreme rulers. This form of organising economic life was beneficial to all. The efforts of many thousands of people were used to create and maintain in working condition complex irrigation systems in Ancient Egypt, protective dams and canals to drain water in the valleys of the Ganges and the Yellow River. Residents of the state received protection from foreign enemies and internal disputes and conflicts were resolved rather efficiently. People had the chance to provide themselves and their families with enough food and in the event of a crop failure the government provided assistance, which meant that they did not die of hunger. When labour productivity is low and transaction costs are high, the government must have the unconditional right to make the most important economic and political decisions. Otherwise the weak government will not be able to protect its citizens from foreign enemies and the standard of living will be lower than in the case of a centralised government. A little later came land ownership of major feudal lords. The profit that they obtained from their land was spent on maintaining armed forces to protect their property and was also used to maintain a large army of tax collectors and supervisors. An increase in labour productivity and a reduction in transaction costs of exchange led to peasants having the opportunity to rent land plots or purchase them from their feudal lords. This is how private land ownership came about. In countries where the political elite were not so averse to this development of events, private ownership received legal support. Laws were created that firmly established the rights of ownership, which further reduced transaction costs of exchange 
and the ownership of property. The countries where this took place quickly became the economic leaders of Europe. Land property appears when the profit from its use or exchange exceeds the transaction costs of the ownership of this asset and the transaction costs of its exchange for another asset. This is how property was established for slaves, windmills, ploughs, factories, plants and petrol stations. In countries where labour productivity was low and the authorities were against the arrival of new owners and created additional transaction costs, private property came about later or has not yet come at all. Most wars and conflicts have had something to do with an attempt to obtain additional property. They were led by countries in which the political elite or a broad class of proprietors were able to earn big profits from owning offshore property. Conquering colonies enabled authority structures, political groups, merchants, mariners and producers of industrial goods to earn huge profits from trading in new land. Under these conditions all the many owners should have political rights because the economic development of the country depends on their actions. The amount of economic growth depends on the amount of their profits. In order to expand their rights they very often shared profits with the ruling elite and received additional political support. This is how the expansion of the political rights of merchants, ancient money changers, the first bankers and owners of the trading fleet took place. The political and economic institutes created at the time depended on their votes and their money.

Institutes are very important; their quality determines the amount of transaction costs. Institutes are created by people. The more people that take part in the creation of institutes the more successful they are. The more people that receive profit from the effects of a certain law or the activity of a certain institute, the higher the level of economic growth. For this reason, under the present conditions only a democracy is capable of producing efficient institutes. Hundreds of years ago when all property belonged to feudal lords, kings, the Church and pharaohs, institutes and laws were created by the country's elite. And this is fair because the entire economic life in the country depended on their actions, they made most of the economic exchanges and they were responsible for the country's development. Nowadays everybody owns property and therefore every vote is important when laws are passed. Institutes are, of course, also created by individuals, parties and non-government organisations. Institutions such as these are undergoing the test of time. If they do not meet the needs of the majority then, in a democracy, these institutes will be rejected. Good institutes allow everybody to earn additional profit, or the majority of people at least. They enable them to attain a high level in the production of goods or services. In authoritarian countries institutes are created by the minority and in the interests of the minority. It is normally the case that profit held by a minority is received due to the worsening of conditions for the majority. Therefore the total profit in these countries is much lower than in successful countries. This is why under a dictatorship economic growth is either low or negative.

Ask yourself a simple question: which branch of the economy are you least satisfied with? The answer will be as follows: healthcare, primary education, defence, community services. Of course, in different countries this list will be slightly different. But all these industries will have two important things in common: a lack of a full market for goods and services and also a considerable level of government intervention. The lack of a market means a lack of private 
property. Private ownership for particular goods or resources is not possible if the profit received from their use is less than the transaction costs of exchange. There are a number of reasons that may explain this. Firstly, it may be so that people have not learned to use the goods or resources efficiently. The profit that the reputed owner receives is less than the costs. It does not make any sense to obtain that resource. Secondly, existing laws may not be good enough to lower transaction costs to an acceptable level. Thirdly, government intervention itself creates additional costs and prevents the establishment of full rights of ownership. These three reasons are the main causes for so-called "market failures". "Market failures" occur when there is no market. In order to try to create one, laws must be adopted which reduce the transaction costs of exchange and the government must be removed from the market if it is creating additional costs. But even in this case a market may not develop. The only possibility left is to learn to use the product or resource in a more productive manner. This may require a great deal of time, but there is no other choice. We simply have to wait, hope and believe in the outcome.

Newton's first law states that if there are no forces acting on an object it will move in a straight line and at a constant speed for an indefinite period of time. What is the practical sense of this law? There is no sense if we do not look at the real forces that act on the object. If there are no forces acting on an object, a railway carriage for example, then you could tap it with your foot and it would move forever. Why then create steam engines and internal combustion engines? Why build roads and dig tunnels? Newton's first law only makes practical sense when we begin to consider the real forces that have an effect on the motion of an object. For example, if we consider that the force of friction prevents movement then we will try to reduce it. And since we will never be able to eliminate friction we begin to create different engines that can overcome friction and move at speed. This all fully relates to the Coase Theorem. It only makes sense and has practical significance in the real world where there are transaction costs of exchange. In my opinion the theorem should read something like this: as transaction costs decrease economic growth increases and as transaction costs increase economic growth decreases. This formulation enables us to understand why laws and institutes are good, bad and very bad. Why did the Arab revolutions take place? Why do people defend their rights and seek democracy? Why do dictatorships always die out? Why will the barriers of barbed wire and government borders soon disappear? The world is rapidly changing. The world is becoming wealthier and safer. This is happening because people are seeking to earn profit and, in doing so, enable all of society to prosper. People are trying to reduce their costs and they will certainly do so. I do not know how rapidly the world will change, but I am sure of one thing: before we know it we will not be able to find a political map of the world anywhere where the countries are pictured in different colours and the borders are marked with solid dark lines. These maps will disappear from our lives forever and will only be of interest to antique lovers, seasoned collectors or staff at history museums.

\section{References}

Acemoglu D., Johnson S., \& Robinson J. (2005). Institutions as the Fundamental Cause of Long-Run Growth. P. Aghion, J.N. Durlauf (eds). Handbook of Economic Growth. Vol. 1A. New York. Elsevier. P. 385-472. 
Arrow K. (1969). The Organization of Economic Activity: Issues Pertinent to the Choice of Market versus Non-Market Allocation. In: Joint Economic Committee. The Analysis and Evaluation of Public Expenditures: The PPB System. Washington, DC: Government Printing Office. P. 47-64.

Banerjee A., Gertler P. J., \& Ghatak M. (2002). Empowerment and Efficiency: Tenancy Reform in West Bengal. Journal of Political Economy, 110(2), 239-280. http://dx.doi.org/10.1086/338744

Barro R. J., \& Sala-i-Martin X. (2004). Economic Growth. Second Edition. The MIT Press. P. $10-14$.

Bates R. H. (1981). Open Economy Politics. Princeton. Princeton University Press.

Baumol W. J. (1982). Contestable Markets: An Uprising in the Theory of Industry Structure. American Economic Review, 72, 1-15.

Bilych G. (2012). Profit and Economic Growth. Business and Economic Research, 2(2)

http://dx.doi.org/10.5296/ber.v2i2.2285

Bowles S. (2004). Microeconomics. Behavior, Institutions, and Evolution. Russel Sage Foundation. New York. Princeton University Press.

Braudel F. (2011). Civilisation Materielle, Economie et capitalisme, XV-XVIII Siecle. Tome 1. Les Structures du Quotidien: le Possible et L`impossible. Armand Colin. Rus.

Bridgeman S. (1955). Reflections of a Physicist. $2^{\text {nd }}$ ed. New York: Philosophical Library. P. 450 .

Brown M., Falk A., \& Fehr E., (2002). Contractual Incompleteness and the Nature of Market Interactions. CEPR Discussion Paper. No 3272.

Buchanan J. M. (1979). Politics without Romance: A Sketch of Positive Public Choice Theory and its Normative Implications. IHS - Journal. 3: B 1-11.

Coase R. H. (1960). Problem of social cost. The Journal of Law and Economics, 3(1), 1-44. http://dx.doi.org/10.1086/466560

Coase R. H. (1988). The Firm, the Market and the Law. Chicago, London. The University of Chicago Press.

Cooter R. D. (1987). Coase Theorem. In: The New Palgrave: A Dictionary of Economics. (eds. Eatwell J., Mitigate M. and Newman P.). L.: Macmillan. 1, 457-460.

Demsetz H. (1967). Toward a Theory of Property Rights. American Economic Review, (57), 61-70.

Djankov S., \& LaPorta R. (2003). Courts. Quarterly Journal of Economics, 118, 453-517. http://dx.doi.org/10.1162/003355303321675437 
Gleaser L., \& Shleifer A. (2002). LegalbOrigins. Quarterly Journal of Economics, 117, 1193-1230.

Greif A. (1994). Cultural Beliefs and the Organization of Society: A Historical and Theoretical Reflection on Collectivist and Individualist Societies. The Journal of Political Economy, 102(5), 912-950. http://dx.doi.org/10.1086/261959

Greif A. (2006). Institutions and Path to the Modern Economy: Lessons from Medieval Trade. Cambridge: Cambridge Press. http://dx.doi.org/10.1017/CBO9780511791307

Heiner R. (1983). The Origin of Predictable Behavior. American Economic Review, 73(4), $560-595$.

Hess G., \& Morris C. (1996). The Long-Run Costs of Moderate Inflation. Federal Reserve Bank of Kansas City Economic Review. Second Quarter, 71-88.

Jenkins I. (1980). Social Order and the Limits of the Law. Princeton (NY): Princeton University Press. 5.

Johnson S. (2000). Coase and Corporate Governance in Development. Villa Workshop Series.

Khan M., \& Senhadji A. (2001). Threshold of Effects in the Relationship Between Inflation and Growth. IMF Staff Papers, 48, 1-21.

Ledyard J. O. (1987). Market Failure. In: The New Palgrave: A Dictionary of Economics. (eds. Eatwell J., Mitigate M. and Newman P.). L.: Macmillan. Vol. 1.

McGee J. S. (1958). Predatory Price Gutting: The Standard Oil (N.J.) Case. Journal of Law and Economics, 1, 137-169. http://dx.doi.org/10.1086/466547

De Mesa D. (1987). Entry on Coase. In: The New Palgrave: A Dictionary of Economics. (eds. Eatwell J., Mitigate M. and Newman P.). L.: Macmillan. Vol. 1.

North D. C., \& Thomas R. P. (1973). The Rise of Western World: A New Economic History. Cambridge. Cambridge University Press.

North D. C. (1990). Institutions, Institutional Change, and Economic Performance. Cambridge: Cambridge University Press. http://dx.doi.org/10.1017/CBO9780511819438

North D. C. (2005). Understanding the Process of Economic Change. Princeton University Press. http://dx.doi.org/10.1017/CBO9780511808678

Pigou A. C. (1920). The Economics of Welfare. London. (In Rus.: Progress. 1985).

Romer D. (2003). Misconceptions and Political Outcomes. Economic Journal, 113, 1-20. http://dx.doi.org/10.1111/1468-0297.00092

Stigler G. (1966). The Theory of Price. New York.: Macmillan.

Weimer D. L., \& Vining A. R. (1992). Policy Analysis: Concepts and Practice. $2^{\text {nd }}$ ed. Englewood Cliffs. N.J.: Prentice Hall. 


\section{Macrothink}

Business and Economic Research ISSN 2162-4860 2013, Vol. 3, No. 1

Williamson O. E. (1985). Behavioral Assumptions. In: O.E. Williamson. The Economic Institutions of Capitalism. Firms, Markets, Relational Contracting. N.Y.: The Free Press. P. 44-52.

Wittman D. (1989). Why Democracies Produce Efficient Results. Journal of Political Economy, 97, 1395-1424. http://dx.doi.org/10.1086/261660

\section{Copyright Disclaimer}

Copyright reserved by the author(s).

This article is an open-access article distributed under the terms and conditions of the Creative Commons Attribution license (http://creativecommons.org/licenses/by/3.0/). 